\title{
CHALLENGING BEHAVIOUR AND POSSIBILITIES OF MANAGING IT THROUGH THERAPEUTIC INTERVENTION
}

\author{
Zuzana Fábry Lucká1, Zuzana Ťulák Krčmáriková \\ ${ }^{1}$ Dr., Comenius University, SLOVAKIA, lucka4@uniba.sk \\ ${ }^{2}$ Dr., Comenius University, SLOVAKIA, tulak@fedu.uniba.sk
}

\begin{abstract}
The presented study focuses on aspects of challenging behaviour in preschool children, with difficulties in sensory processing. It points out the possibilities of therapeutic interventions through which it is possible to identify challenging behaviour in a peer environment, but also proposes strategies in the approach to such a child. The aim of the study is to describe specific methods and techniques for dealing with challenging situations. This paper is a partial output of the KEGA project no. 002UK-4/2020 Support for a child with a sensory processing disorder through a multisensory environment.
\end{abstract}

Keywords: Challenging behaviour. Preschool child. Therapeutic intervention.

\section{CHALLENGING BEHAVIOUR}

Children communicate through behaviour, even after they have developed speech. Children's non-verbal expression can show dissatisfaction with a situation from an early age, because the verbal expression is not yet at such level that would allow them to formulate their needs and fears, whether to a close person or to a person from the wider social environment. In preschool age, movement allows social play in a group. In kindergartens, it is naturally included in almost every game. Physical culture is recognised as inherent part of preschool upbringing and education (Tashpulatov \& Shermatov, 2021).

Recognising nonverbal expression is an important competence not only for parents but also for kindergarten teachers. Children can manifest different emotions such as nervousness, fear, but also joy on a physical basis. They not only communicate feelings through movement but also experience strong emotions primarily through the body. Thus, the non-verbal expression of a moving child offers the observer several pieces of information that can be abstracted. In order to analyse them it is important to focus on body posture, psychomotor skills, facial expressions and gestures, their suitability for the situation, vocal expression (intensity, tone of voice, screaming), tendency to bodily contact. Other aspects can be noticed too, such as tendency to make physical contact, to touch other children as well as adults. The information obtained mainly reflects the child's experience in terms of positive and negative emotions, experienced joy, relaxation, or, conversely, sadness, tension, fear and needs to be interpreted in this way.

Challenging behaviour in children can have various causes. It can be induced by an organic cause, damage (pre, peri or postnatal), the influence of psychological and social influences or a physiological and emotional burden that the child cannot (does not know how to) cope with (Tichá, 2015). For a child as well as for an adult, it is often difficult to define in words what is hidden behind the expressed emotion that will "control" 
them - take over their behaviour - at a given moment. The observer sees an expressed emotion that does not correspond to the general understanding of the situation. It is exaggerated, sometimes incomprehensible or even destructive. By feeling misunderstood and deceived, punished or isolated for a given emotional expression, the child faces additional feelings of frustration, misunderstanding and helplessness. However, this does not lead to a solution, understanding and correction, but on the contrary, it contributes to perpetuating the original inappropriate behaviour.

The child hears how bad, rude, aggressive they are until they can become what they were convicted of and labelled as, as if it was their "license plate". It affects their self-confidence, self-esteem, self-perception. They do not see the point in changing their behaviour because they have not been heard, understood, no one cares what lies behind their behaviour. If the child is not led to safely express feelings including the negative ones, they cannot learn to understand them.

Challenging behaviour can occur without a different diagnosis, or it can be the result of an inappropriate approach or unresolved problems resulting from a particular diagnosis, e.g., neurodevelopmental disorders such as attention deficit hyperactivity disorder, autism spectrum disorder, learning disability. In any case, challenging behaviour has its long-term causes (Lessner Lištiaková, 2017).

Siegel and Bryson (2015) emphasised the importance of children learning about their feelings and learning to understand them. At the same time, however, feelings must be recognised as they are: as temporary and changeable states. Paulík (2017) states that negative emotions burden children not only primarily but also secondarily, e.g. as a provocative moment of interpersonal conflicts. This includes anger and aggressive tendencies, which occur quite naturally and can result from frustration, fatigue or can be emotionally induced. Anger and aggressive tendencies are easily transmitted from person to person.

It is in movement expression that the first problems in the child's behaviour are most often reflected, in one of the three polarities - submissive, ambivalent, or aggressive expression. The child's range of physical manifestations towards the environment can serve as a predictor of problem behaviour even in the case of a latent form of aggressive behaviour (Kováčová, 2014). Abnormal behaviour can also be a symptom of a sensory processing disorder. In their research work, Shimizu, Bueno and Miranda (2014) investigated the relationship between sensory processing disorders and challenging behaviour with hyperactivity. In the research sample, children with a diagnosed behavioural disorder and children with normal development were included and compared. The Child Behavior Check List (CBCL) and the Behavioral Teacher Rating Scale (EACI-P) examined the relationship between behavioural disorders and sensory processing disorders. Based on the research results, this connection was confirmed, especially in the field of modulation.

Clark and Kingsley (2020) state in their study that the development of cognitive, motor and self-care activities in the preschool age of the child is a prerequisite for building other, so-called life competences, including satisfactory social relations with a peer group without hidden manifestations of aggression. Tanner et al. (2020) addressed the issue of delayed psychomotor development and compared 56 studies focusing on motor skills in children from birth to the age of five. Based on research findings, they recommend that interventions always be combined with a locomotor element from an early age; they identify the importance of early intervention as an overlap into preschool age, i.e., within a period of five years. If the intervention is clear and targeted, there is a presumption of better social inclusion in the group in kindergarten.

\subsection{Research design}

In 2019, a research study was carried out for a period of six months by applying a psychomotor program to support sociomotorics - social relations and ties in a group of children where there were also children with disabilities. The implementation of the psychomotor program took place during the period from September 2019 to February 2020 in four phases:

1. Preparatory phase: Selection of kindergarten, study of materials, creation of conceptual apparatus.

2. Diagnostic phase: Implementation of simple movement games in a group.

3. Implementation phase: Implementation of a psychomotor program aimed at supporting sociomotorics.

4. Interpretation and analysis: Analysis of findings, variables that were identified during the implementation of the psychomotor program. Recommendations for practice.

Based on the description of the issue, we decided to focus the research on the period of children's life in which they attend kindergarten - from 3-6 years (preschool age). The research was conducted in two larger kindergartens, each of them with more than four classes and with children identified as having specific developmental disadvantages. 
The research study used a case-study format, focusing on a child identified in the diagnostic phase as manifesting severe behavioural challenges. The behavioural manifestations are described to demonstrate a justification for an intervention through psychomotor activities. The applied programme of psychomotor activities focused on social interactions and it is not described in detail, however, the generalised findings are presented in a form of recommendations for further programmes.

\subsection{Results}

In the group of children in the preschool class, one dominant boy was identified, who acted predominantly in verbal and nonverbal speech not only towards the child with otherness (differences), but also towards the others in the peer group.

Manifestations of aggressive behaviour appeared to an increased extent, especially when there was no adult nearby - teacher, assistant, other staff. Through observation physical activities, we identified the following variables as the main issues in this group of preschool children:

- Rejection of non-verbal communication, focusing explicitly on verbal expression only.

- The child's non-verbal expressions do not correspond to the nature of the situation in which he finds himself.

- The intensity of nonverbal expression is very high or very low.

- The child attracts attention only by loud verbal expression.

- The child does not seek physical contact with close family members.

- The child refuses physical contact in a peer group.

- The child refuses physical contact in general, deliberately avoiding it.

In our research, we also identified obvious aggressive manifestations in three areas:

1. Aggressive expression directed towards oneself if anything deviates from the limits set by the child - selfharm, scratching of sensitive parts of the body, tearing of clothes, banging on the body until complete anaesthesia.

2. Aggressive behaviour directed at objects in its vicinity, whether in its possession or in the possession of another peer.

3. Aggressive behaviour towards loved ones - the child does not manifest aggressively in the group, their target is one of the family members.

In addition to the apparent aggressive forms of behaviour listed above, we have also identified latent manifestations of aggressive behaviour towards a child with autism spectrum disorder. Manifestations were identified and also confronted through movement games within the implemented psychomotor program.

Based on the implemented interventions, we identified the following needs in the implementation of the intervention program for preschool children:

- come into basic interactions,

- create peer groups, become part of peer groups,

- getting to know each other's peers through activities of interest to them (getting to know each other is more natural and more understandable for the child),

- develop fine motor skills, develop gross motor skills,

- provide the child with sufficient stimuli for development, especially suitable natural material (water, sand, stones, grass, chestnuts),

- sufficient physical activity, such as walking uphill, climbing up and down, jumping, hiking, crawling, twisting and turning, rolling,

- use the child's magical thinking, creativity and imagination in activities,

- ensure orientation not only in space but also in time,

- use the child's verbal expression - poems and songs that the child knows, learns (using the child's own 
potential),

- set rules together with the child, establish group rules and compliance,

- enable the child to express themselves in a way other than by movement - for example by drawing, painting.

Combining movement (psychomotor) therapy with other modalities, especially art-based activities proved to be especially suitable for preschool children, and it facilitated the understanding of children's behavioural expressions. Colours say a lot about a child. In particular, the use of colour combinations has diagnostic and therapeutic potential. Red combined with green or black is a combination of conflict and aggression. Using only dark colours signals depression to the therapist, as well as low self-esteem and a disturbed self-image. Colours have a psychological, aesthetic and cultural context. The influence of colours and colour combinations on the mental and physical health of a person is proven. Their effect is individual. An expert can also use the symbolism of colours to better understand the symbolism of the colour expressions of the children. It is necessary to know the laws of colour perception, the laws of psychological effects of colours, but also the properties of colours such as heat and cold, lightness and darkness of colours, to orientate oneself in the category of basic and complementary colours. If the expert is aware of the complementary colour rule, their ability to diagnose through a colour art product increases. They are able to recognize harmony in the colour combinations of the child's picture and, conversely, inconsistency. The symbolism of individual colours is also important. Children paint in a more free way and their paintings are more colourful compared to adults' paintings. In an art product, we notice the preference for certain colours as well as the meaningfulness or logic of its use.

\subsection{Conclusion}

In general, from the point of view of the perception of self-concept - one's own physicality, it is important to take into account the child's authenticity and developmental potential, use their strengths and expose the child to appropriate developmental tasks (Zimmer, 2019).

We also consider it necessary to mention the basic principles for the implementation of this type of programme, which we have formulated on the basis of the identified variables throughout the duration of the programme. It is especially important to adapt the conditions for the child so that:

- The environment is safe for them,

- They have the opportunity to express themselves freely without endangering other peers,

- They experience a sense of success, whether in individual or group form,

- They gain self-confidence through activities focused on coordination of movements, balance, fine and gross motor skills,

- They have the opportunity to interact with each other, to find creative solutions, to learn to overcome obstacles in different ways, and to learn to manage different life situations,

- They do not place demands on each other that are too high,

- Their developmental potential has been used,

- They are not compared with other peers in the group,

- They develop mobility, response speed, catching, throwing, speed and strength,

- Movement is combined with other therapeutic media, such as music or fine arts, as much as possible.

Combining therapeutic interventions is a suitable way to comprehensively support a child in preschool age with challenging behaviour. Utilising the potential of movement (Vodičková, 2020), music (Habalová, 2021), play (Mitašíková, 2018) or fine arts (Ťulák Krčmáriková, 2017) allows the child to express themselves in the form that is natural for them.

An intervention program focused on social relations and ties is a suitable form of prevention of aggressive behaviour, whether that is in its clear manifestations or hidden forms. In group cooperation and in games where it is necessary to express oneself non-verbally, the teacher also has the opportunity to identify problems in the group and solve them through targeted activities. Especially if there is also a child with a difference in the group (such as a developmental disability), it is important to diagnose the group as a team that is not endangering for any of the members. Movement is a natural activity for the child, together with the 
use of other intervention strategies, it has the potential to attract children, specifically address social relationships in the group and thus prevent aggressive behaviour between peers.

\section{REFERENCE LIST}

Clark, G.F., Kingsley, K. L. (2020). Occupational Therapy Practice Guidelines for Early Childhood: Birth-5 Years. American Journal of Occupational Therapy. Volume 74, Issue 3. doi:10.5014/ajot.2020.743001.

Habalová, M. (2021). Možnosti hudby pri podpore vnímania u detí vo včasnej intervencii. In Studia Scientifica Facultatis Paedagogicae. Ružomberok: Verbum. Číslo 3, jún 2021, ročník 20. 2021. ISSN 1336-2232.

Kováčová, B. (2014). Latentná agresia v škole. Bratislava: Musica Liturgica, 2014. 97 s. ISBN 978-8089700-02-8.

Lessner Lištiaková, I. (2017). Liečebnopedagogická intervencia prostredníctvom multisenzorických prístupov pri problémoch v správaní detí. In Lessner Lištiaková, I. (Ed.). 2017. Liečebnopedagogické intervencie pri poruchách správania detí. Bratislava : Univerzita Komenského v Bratislave, 2017. 174 s. ISBN 978-80-223-4454-8.

Mitašíková, P. (2018). Kontext rodiny ako základ liečebnopedagogickej intervencie. In Fábry Lucká, Z. (Ed.). 2018. Rodina v procese zmien. Bratislava: Univerzita Komenského v Bratislave, 2018. s. 8 - 21. ISBN 978-80-223-4645-0.

Paulík, K. (2017). Psychologie lidské odolnosti. Praha: Grada, 2017. ISBN 978-80-247-5646-2.

Shimizu, V. T., Bueno, O. F, Miranda, M. C. (2014). Sensory processing abilities of children with ADHD. Brazilian Journal of Physical therapy. 18(4): 343-52. doi: 10.1590/bjpt-rbf.2014.0043.

Siegel, D., J., Bryson, T. P. (2015). Rozvijajte naplno mozog svojho diet'at'a - 12 revolučných stratégií, ako kultivovat' zrejúcu dušu vášho diet'at’a a pomáhat' rastu jeho EQ. Brno: Cpres, 2013. ISBN 978-80264-0869-7.

Tanner, K., Schmidt, E., Martin, K., Bassi, M. (2020). Interventions Within the Scope of Occupational Therapy Practice to Improve Motor Performance for Children Ages 0-5 Years: A Systematic Review. American Journal of Occupational Therapy. Volume 74, Issue 2. doi: 10.5014/ajot.2020.039644.

Tashpulatov, F. A., \& Shermatov, G. K. (2021). Place and Role of Physical Education in the General System of Education of Preschool Children. International Journal of Development and Public Policy, 1(5), 7780.

Tichá, E. (2015). Etiológia porúch správania. In Tichá, E. (Ed.). 2015. Teoretické východiská porúch správania. Bratislava: Univerzita Komenského, 2015. ISBN 978-80-223-3994- 0. s. 29-39.

Ťulák Krčmáriková, Z. (2017). Liečebnopedagogická intervencia prostredníctvom arteterapie pri problémoch v správaní detí. In Lessner Lištiaková, I. (Ed.). 2017. Liečebnopedagogické intervencie pri poruchách správania detí. Bratislava: Univerzita Komenského v Bratislave, 2017. 174 s. ISBN 978-80-223-44548.

Zimmer, R. (2019). Handbuch Psychomotorik. Zlín: Graspo CZ., 2019. ISBN 978-3-451-3858-3.

Vodičková. B. (2020). Od psychomotorickej expresie cez psychomotorickú výchovu k psychomotorickej terapii. In Kováčová, B., Valachová, D. Expresivita v (art)terapii III. Bratislava: Univerzita Komenského. 2020. ISBN 978-80-223-5021-1. 